\title{
Research on the construction of multilevel economic management virtual simulation experimental teaching center
}

\author{
Wenbo Deng \\ Heyuan Polytechnic, Heyuan, Guangdong, 517000, China \\ wenbodeng@163.com
}

Keywords: Multilevel, Economics and management major, Virtual simulation, Experimental teaching center.

\begin{abstract}
Virtual simulation experiment teaching is an important means to improve the skills of students majoring in economics and management. And it can make the theoretical knowledge that the student learns in the school seamlessly dock with the actual enterprise, and make the student better adapt to the work position of the enterprise. Through summing up the experience of many years' experiment teaching, the author puts forward that the construction of virtual simulation experiment teaching center should be carried out from the aspects of laboratory, virtual simulation platform, curriculum and teachers, which has a good reference for other similar colleges and universities.
\end{abstract}

\section{Introduction}

With the rapid development of China's social economy, modern enterprise management activities become more and more complex and comprehensive. Therefore, enterprises have put forward higher requirements for the quality and ability of economic and managerial talents. Practice teaching is an important way to cultivate students' skills and qualities. Therefore, various domestic colleges and universities have made various attempts in practice teaching mode and accumulated certain experience. Various practical teaching modes can be divided into two types. One is the mode of school enterprise cooperation based on post practice. The other is to enhance students' comprehensive application ability by adding in school experiments or training courses. The mode of school-enterprise cooperation is often confronted with the contradiction between the "wide-caliber" goal of talent cultivation in Colleges and universities and the "specialization" of talent demand in enterprises. However, the practice teaching mode based on a single major in schools often conflicts with the dynamic demand for management talents in enterprises. With the rapid development of computer technology, virtual simulation experiment based on computer simulation, multimedia and virtual reality technology is widely used in practice teaching of economics and management specialty. For example, in the virtual simulation experiment teaching, the students can use the computer system to complete various scheduled experimental projects, the experimental process as in the real environment, so as to achieve the same or even better learning results as in the real environment.

\section{The significance of the construction of virtual simulation experimental teaching center}

\subsection{Breaking through the bottleneck of practical teaching and making up for the shortage of practical teaching resources}

Theoretically speaking, the practice mode of off campus enterprises is the most effective way to cultivate students' skills. However, in many years of teaching practice, it is found that this mode is facing great difficulties. Because the students majoring in economics and management are facing the post of enterprise management, and the post knowledge, skills and experience of the students participating in the internship are not enough to fulfill the responsibility of the management post. If they finish the classroom teaching and go directly to the enterprise post internship, there will be a 
great probability of working errors, which will bring great losses to the enterprise. In order to break through the bottleneck of the lack of practice opportunities outside school, schools can make up for the shortage of practice outside school by constructing a realistic virtual simulation environment for students to carry out experiments in the virtual environment.

\subsection{It helps students to develop their abilities and qualities in an all-round way so as to achieve seamless employment of graduates.}

Multilevel virtual simulation experiment teaching is to explore the basic skills, professional skills and comprehensive skills of students step by step on the basis of the training objectives of talents. Students complete interactive tasks in high-level simulation environment, effectively improve their professional skills and comprehensive skills, and through graduation practice to test and solidify the skills trained. Through the experiment and practice, the graduates of economics and management major have the corresponding skills directly engaged in grass-roots management posts, and realize the seamless connection between the talents training of economics and management major in Higher Vocational Colleges and the needs of enterprises.

\subsection{It helps to cultivate economic and managerial talents with innovative and entrepreneurial abilities.}

In the virtual simulation training, the students of economics and management are organized to play the roles of different posts in all kinds of organizations, carry out collaborative training, and complete the tasks of market research, location, business registration and operation. Work tasks are motivated by real market mechanisms. Students from different majors need to learn from each other in order to accomplish common tasks and achieve inter-organizational collaboration. What is more crucial is that students need to use innovative thinking to analyze and solve problems, which are conducive to the cultivation of innovative and entrepreneurial ability of compound talents.

\section{Multilevel characteristics of virtual simulation experiment teaching center}

\subsection{Multi level of virtual simulation teaching platform}

According to the level of simulation technology, virtual simulation platform can be divided into three levels, sand table simulation, computer simulation and virtual reality simulation. The experimental teaching platform of sand table simulation layer includes sand table simulation training system for enterprise operation, sand table simulation training system for logistics management and sand table simulation training system for marketing. Computer simulation layer includes business platform, 3D logistics simulation platform, Intel marketing simulation platform, Bizwar enterprise management and training platform and other professional simulation platform. The virtual reality simulation layer is a virtual business environment simulation operation integrated platform.

\subsection{Multilevel Curriculum}

According to the different stages of students' theoretical knowledge learning, we construct different levels of virtual simulation technology, platform and curriculum as shown in Table 1.

As shown in Table 1, the simulation level is divided into three levels according to the basic professional ability, professional technical ability and comprehensive ability in the training objectives of economics and management professionals. For example, the corresponding simulation technology level of basic ability level is sand table simulation, the platform level is all kinds of sand table simulation platform, and the corresponding curriculum level is sand table simulation training course. With three levels of virtual simulation teaching platform, a virtual simulation experiment course is constructed. 
Table 1 multilevel of virtual simulation

\begin{tabular}{llll}
\hline Hierarchy & $\begin{array}{l}\text { Simulation } \\
\text { technology } \\
\text { level }\end{array}$ & Platform level & Curriculum level \\
\hline $\begin{array}{l}\text { Basic } \\
\text { competence } \\
\text { level }\end{array}$ & $\begin{array}{l}\text { sand table } \\
\text { simulation }\end{array}$ & $\begin{array}{l}\text { sand table simulation training system } \\
\text { for enterprise operation, sand table } \\
\text { simulation training system for logistics } \\
\text { management and sand table simulation } \\
\text { training system for marketing }\end{array}$ & $\begin{array}{l}\text { Sand table simulation } \\
\text { training course }\end{array}$ \\
\hline $\begin{array}{l}\text { Professional } \\
\text { skill level }\end{array}$ & $\begin{array}{l}\text { computer } \\
\text { simulation }\end{array}$ & $\begin{array}{l}\text { Business Platform, 3D Logistics } \\
\text { Simulation Platform, Intel Marketing } \\
\text { Simulation Platform, Bizwar Enterprise } \\
\text { Management Training Platform, etc. }\end{array}$ & $\begin{array}{l}\text { Professional simulation } \\
\text { experiment courses }\end{array}$ \\
\hline $\begin{array}{l}\text { Comprehen } \\
\text { sive } \\
\text { capability } \\
\text { level }\end{array}$ & $\begin{array}{l}\text { Virtual } \\
\text { reality } \\
\text { simulation }\end{array}$ & Virtual business environment simulation \\
operation integrated platform & $\begin{array}{l}\text { Economics } \\
\text { management } \\
\text { interdisciplinary } \\
\text { simulation training }\end{array}$ \\
\hline
\end{tabular}

\section{Construction contents of multilevel virtual simulation experimental teaching center}

\subsection{Construction of virtual simulation laboratory and experimental platform}

In 2007, Heyuan Polytechnic built sand table training room, ERP training room and manual accounting training room. In 2012, the school began to invest a large amount of money in the construction of virtual simulation training. And teachers actively participate in the virtual simulation teaching team. On this occasion, the school expanded the comprehensive logistics training room, built ERP training room 2, cross-disciplinary virtual simulation training room, e-commerce training room and so on. After five years of teaching practice, virtual simulation practice teaching mode has been recognized by school leaders, professional teachers and students.

\subsection{Construction of virtual simulation experiment teaching}

Since 2008, Heyuan Polytechnic has offered the course of "Simulation Training for Enterprise's Overall Operation of Sand Table", which is a simulation course for freshmen majoring in economics and management. It was set up as an excellent resource sharing course in Guangdong Province in 2014. In recent years, with the development of computer simulation technology, our school has developed many courses such as "Enterprise Operation Practical Training" and "Interdisciplinary Simulation Training in Economics and Management" and compiled a set of teaching materials for virtual simulation experiment teaching according to the needs of course construction, which has perfected the course resources such as video, experiment manual and teaching PPT.

\subsection{Construction of teachers in virtual simulation experiment teaching}

The virtual simulation experiment teaching requires that the work flow of the enterprise should be consistent with that of the real enterprise, and all kinds of unexpected problems triggered by the simulated economic environment should be solved. All these require the virtual simulation experiment center to strengthen the construction of the teaching staff. The virtual simulation experimental teaching center of economics and management can improve the existing teachers' level by introducing talents, taking the old with the new, training the enterprises, hiring part-time teachers and participating in professional training. After 5 years' efforts, the virtual simulation experimental teaching center of economics and management in our college has a group of experienced and skilled teachers, which provides a strong guarantee for the virtual simulation experimental teaching.

\section{Summary}

Relying on computer simulation, multimedia and virtual reality technology, we can build a 
virtual business environment consistent with the real enterprise environment, and apply it to the practical teaching field of economics and management specialty, which can effectively train students' ability and quality. From 2008 to 2017, more than 5000 students majoring in economics and management participated in multi-level virtual simulation training. All kinds of skill competitions organized by students relying on virtual simulation experiment courses have achieved good results. In the past 10 years, 86 provincial and higher awards have been awarded, including more than 20 national first-class awards. In the future work, we will further strengthen the construction of teachers, platforms and courses, and provide high-quality business management personnel for enterprises.

\section{Acknowledgements}

This work was financially supported by the project of Educational Science Planning in Guangdong" Research and Exploration on the practice teaching mode of economics and management-Improving students' comprehensive ability based on multi-level virtual simulation training”(2017GGXJK064)

\section{References}

[1] Wang Dongsheng, Guo shouku. Enterprise-operation-oriented Design on Trans-specialty Virtual Simulation Experiment of Management Discipline [J].Research and Exploration in Laboratory. 2017,36 (12):121-124

[2] XUE Yongji, CHEN Jiancheng, WANG Mingtian. Study and Practice on Virtual Simulation Experimental Instruction in Economics and Management Specialty[J].Research and Exploration in Laboratory.2017,36 (10):283-286

[3] Guo Xinmei, Fang Chengxin. Experience From Construction of National-level Experimental Teaching Center of Virtual Simulation of Economic Management [J]. Experimental Technology and Management.2014,31 (11):8-12

[4]Zheng Shuang, Wu Haidong, Chen Zhaohui, Li Shunhui. Construction and Exploration of Virtual Simulation Experimental Teaching Center for Enterprise Economic Activities [J]. Experimental Technology and Management.2014,31 (11):13-16

[5] Yan Caixia, Bao Kunjin, Bao Lun, Jiang Yuansheng. Creative Construction and Marked Effect of Practical Teaching System with "Twice Recycling, Virtually and Actually Combining” [J]. Experimental Technology and Management.2012,29 (12):145-148 